Самостян В. Р.

Луцький національний технічний університет

\title{
ЕФЕКТИВНЕ ВИКОРИСТАННЯ ПІДХОДІВ ДЛЯ ІМІТАЦЙНОГО МОДЕЛЮВАННЯ ЛОГІСТИЧНИХ ПРОЦЕСІВ
}

\begin{abstract}
В індустріально розвинених країнах імітаційне моделювання логістичних ланцюгів використовується досить широко і рахується звичайною складовою частиною проектів по створенню нових або реконструкції існуючих логістичних ланцюгів. В даній статті були розглянуті три підходи до імітаційного моделювання логістичних систем. Розглядалося застосування різних підходів імітаційного моделювання для оцінки ефективності логістичних процесів. Представлена узагальнена структура імітаційної моделі функціонування логістичної системи. Для іï реалізації запропоновано використання трирівневого комплексу моделей, що використовують різні парадигми імітаційного моделювання. Були розглянуті та окреслені переваги кожного із підходів імітаційного моделювання логістичних процесів, зокрема: системний динаміка, дискретноситуативний підхід, агентний підхід. Визначено призначення моделей кожного підходу: системна динаміка для проектування загальної структури логістичної системи; дискретно-ситуативний підхід - для поліпшення параметрів окремих логістичних процесів; агентний підхід - для незалежного територіально-розподіленого ланцюга поставок. Для прикладу було взято узагальнену імітаційну модель логістичної системи у вигляді «чорного ящика». Запропоновано приклад реалізації рівня дискретно-ситуативних моделей у вигляді трьох типових видів моделей. У середовищі імітаційного моделювання Arena розроблена мультипродуктова модель для оцінки базових показників ефективності логістичної системи: рівень обслуговування, середній рівень запасів, середній рівень затриманих замовлень, загальна кількість втрачених або затриманих замовлень.

В ході подальшої роботи планується наповнення запропонованого комплексу моделей з використанням всіх трьох підходів імітаційного моделювання. В цілому можна зробити висновок, що застосування переваг кожного із підходів імітаційного моделювання $\epsilon$ перспективним і може бути використаний для широкого кола підприємств різних галузей діяльності.

Ключові слова: імітаційне моделювання, логістична система, дискретно-ситуативний підхід, агентний підхід, ланцюги поставок, постачальник.
\end{abstract}

\section{ВСТУП}

Ефективність роботи всієї логістичної системи будь якого транспортного підприємства залежить від своєчасної переробки великих обсягів оперативної інформації та обгрунтованості прийняття відповідальних управлінських рішень. Для досягнення мети транспортних підприємств, в умовах невизначеності і ризику, зводиться до оцінки логістики матеріальних потоків і технологічних операцій на всіх стадіях виробництва від поставок сировини до реалізації готової продукції 3 перебуванням оптимальних рішень в оперативних умовах і довгострокових стратегіях діяльності підприємства.

Стан складної логістичної системи в умовах невизначеності і ризику в більшості випадків непередбачуваний і не може бути прогнозований спочатку аналітично або шляхом логічного аналізу, так як він є результатом багатокрокової взаємодії безлічі матеріальних потоків і активних автономних елементів системи і навколишнього середовища. Аналітичні методи прийняття рішення розглядають статичні стани окремих виробничих сфер без урахування динаміки поведінки кожного активного елементу і його прямого впливу на стан інших елементів.

Оцінка і вибір стратегії виробничої діяльності в невизначеної ситуації поставок, виробництва і попиту на продукцію можлива за допомогою імітаційного моделювання поведінки кожного елемента виробничої системи. Тому, для вирішення задачі оптимізації управління запасами і матеріальними потоками в сферах поставок сировини, його переробки, зберігання i збуту готової продукції $\epsilon$ соціально значущою і актуальною розробка об'єктно-орієнтованих мультиагентних імітаційних моделей стану і поведінки складних логістичних систем підприємства при початковій стохастичній невизначеності виробничих і маркетингових ситуацій.

\section{АНАЛІЗ ЛІТЕРАТУРНИХ ДАНИХ ТА ПОСТАНОВКА ПРОБЛЕМИ}

В умовах жорсткої конкуренції компанії стикаються 3 проблемами мінімізації витрат, максимізації прибутку, поліпшення якості обслуговування клієнтів і зниження впливу факторів невизначеності. Логістика $\epsilon$ однією зі сфер діяльності, що швидко розвиваються та дають підприємствам значні переваги в конкурентній боротьбі. У зв'язку з цим корпоративні структури мають сильну мотивацію до підвищення ефективності управління логістичними процесами для отримання конкурентних переваг. Концепція управління ланцюгами поставок - один 3 найбільш 
стрімко розвинутих напрямків наукової та практичної діяльності протягом останніх десятиліть. Управління ланцюгами поставок означає управління потоком (матеріали, товари, послуги) i забезпечення ефективної інтеграції та координації постачальників, виробників, логістичних та торгових компаній і споживачів. Найбільш складним етапом в управлінні ланцюгами поставок $\epsilon$ процес прийняття рішення, так як необхідно проаналізувати безліч взаємопов'язаних, часто хаотичних подій. Для того, щоб досягти загального зниження витрат в ланцюзі постачань при заданому рівні якості обслуговування кінцевих споживачів необхідно знайти компроміс між вартістю, сервісом, якістю і часом.

Можна виділити три можливих шляхи вирішення подібних завдань: аналітичні (математичні) моделі; фізичні експерименти; імітаційні моделі. Очевидно, що фізичні експерименти вимагають, як правило, великих технічних і фінансових витрат. Використання відомих аналітичних моделей обмежена аналізом щодо простих систем особливо в умовах невизначеності [3-5]. Імітаційне моделювання дозволяє аналізувати логістичні процеси практично будь-якої складності [1]. За допомогою симуляції вже на етапі проектування можна порівняти і оцінити альтернативи реалізацій процесів, провести ряд експериментів з різними показниками («що - якщо») і зробити найбільш обгрунтований і ефективний вибір [3].

\section{ЦІЛЬ ТА ЗАДАЧІ ДОСЛІДЖНЬ}

Метою роботи є дослідження можливостей підходів до імітаційного моделювання для оцінки ефективності і поліпшення логістичних процесів. Використання переваг кожного із підходів до імітаційного моделювання дасть можливість якісно, ефективно та 3 найменшими затратами часу змоделювати логістичну систему.

\section{РЕЗУЛЬТАТИ ДОСЛІДЖЕНЬ}

В індустріально розвинених країнах імітаційне моделювання логістичних ланцюгів використовується досить широко і рахується звичайною складовою частиною проектів по створенню нових або реконструкції існуючих логістичних ланцюгів. Такі компанії, як BMW, Daimler-Chrysler, MercedesBenz, Audi використовують імітаційне моделювання, як інструмент прийняття логістичних рішень. Світова статистика прийняття рішень на основі імітаційних моделей дозволяє говорити про підвищення ефективності управління логістичними процесами в середньому на 10 - 15\% [2].

Для прикладу візьмемо узагальнену імітаційну модель логістичної системи у вигляді «чорного ящика» (рис. 1).

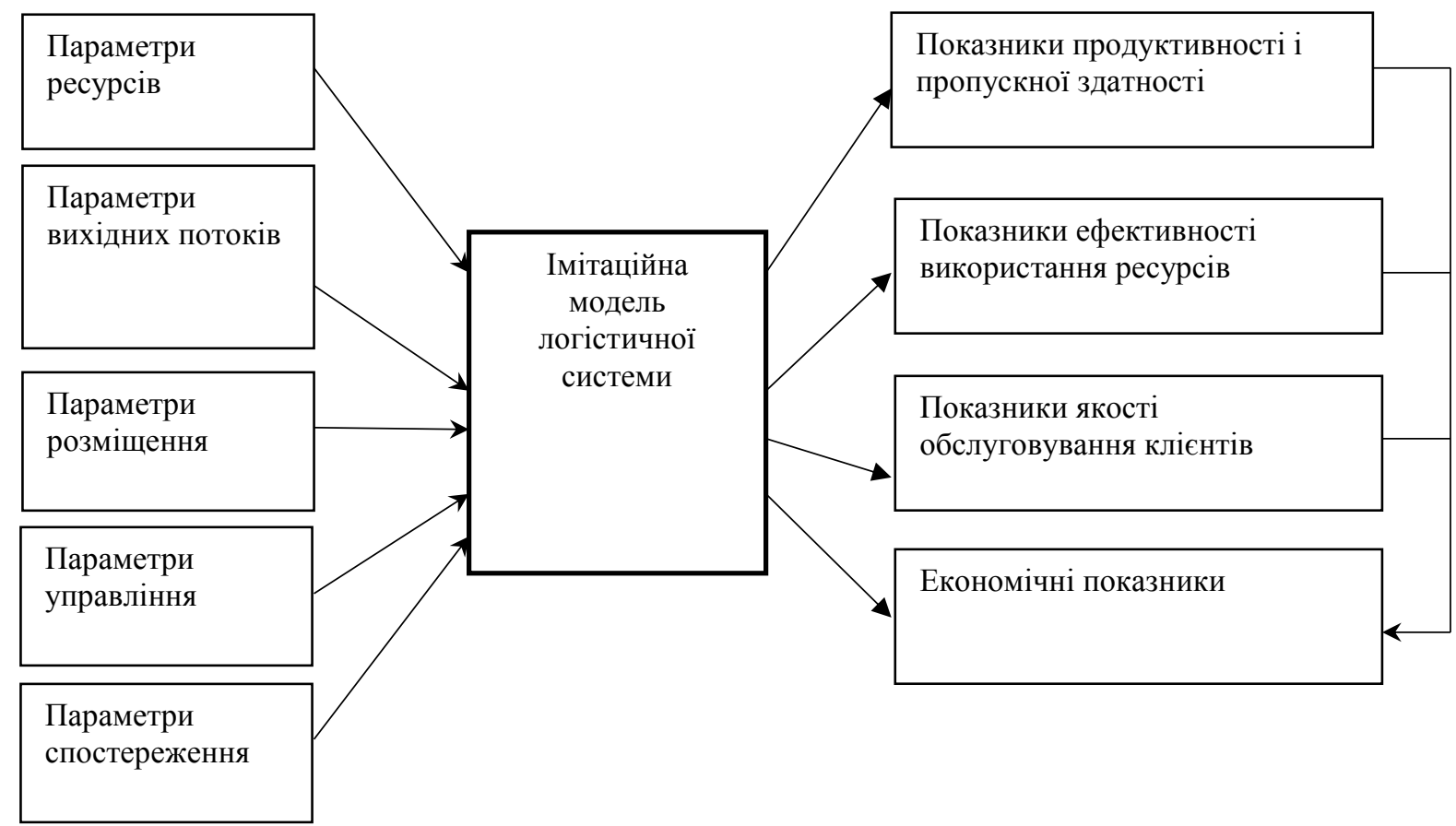

Рисунок 1. Вхідні дані і результати імітаційного моделювання

Первинні показники на виході моделі вимірюються за допомогою відповідних фізичних величин, наприклад, обсяг перевезеного або обробленого вантажу, моменти часу початку і закінчення операцій, сумарний шлях, пройдений транспортними засобами, тощо. Шляхом використання 
відповідних нормативних коефіцієнтів на базі цих показників можуть бути розраховані будь-які необхідні економічні показники. Існує три основних підходи до імітаційного моделювання (системна динаміка, дискретно-точкові і агентні підходи), кожен з яких має свої переваги і недоліки. Парадигма імітаційного моделювання, яка використовується в моделі управління ланцюгами поставок, багато в чому залежить від типу завдань, які необхідно вирішити. Основний критерій, який має важливий вплив на розробку імітаційної моделі логістичних процесів, - це рівень декомпозиції (деталізації) системи.

Схема імітаційної моделі, зображена на рис. 1, може бути реалізована будь-яким 3 підходів імітаційного моделювання. Але не всі логістичні завдання можна вирішити з використанням тільки одного підходу, часто необхідно комбінувати підходи в межах однієї моделі, щоб досягти бажаного результату. Звідси важливим $\epsilon$ комплексність підходу до моделювання логістичних систем, поєднання різних парадигм імітаційного моделювання, що дозволить використовувати перевагу кожної з них. Пропоноване різнопланове моделювання полягає в реалізації комплексу моделей, в якому результати, отримані за допомогою одного типу моделей, можуть бути використані в інших моделях. У створюваному комплексі моделей можна виділити три інтегрованих рівня (рис. 2), рухаючись по яких «зверху-вниз» або «знизу-вгору» можна вирішувати завдання проектування $\mathrm{i}$ оцінки ефективності логістичних систем.

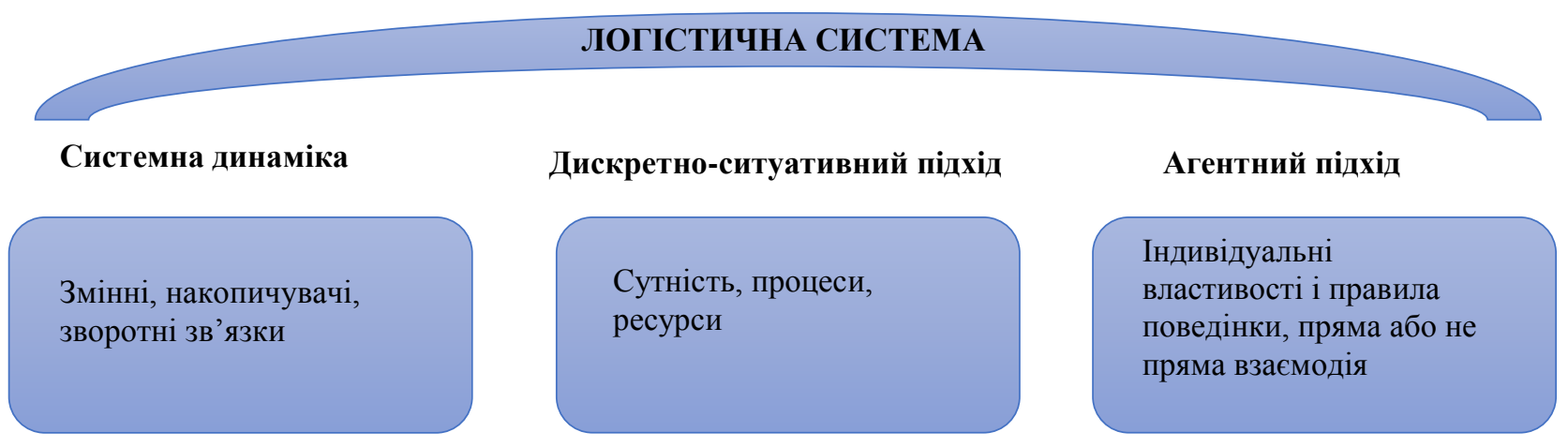

Рисунок 2. Підходи реалізації комплексу логістичних систем

Як правило, вже на етапі розробки концептуальної моделі дослідник точно знає, за допомогою якого підходу імітаційного моделювання модель буде реалізована у вигляді комп'ютерної програми. Тому багато елементів концептуальної моделі (наприклад, типи відображення логістичних об'єктів і ресурсів системи) бувають безпосередньо зорієнтовані на можливості відповідного підходу імітаційного моделювання. Завжди враховується той факт, що в більшості сучасних підходів імітаційного моделювання готова модель представляється як мережева структура, вузли якої $\epsilon$ представниками (об'єктами) відповідних бібліотечних компонентів (класів). Якщо розробник моделі знайомий з конкретним підходом імітаційного моделювання, для нього не складе великих труднощів вибрати в бібліотеці компоненти, найкращим чином відповідні компонентам концептуальної мережевої моделі. Але саме побудова концептуальної мережевої моделі є найбільш складним етапом дослідження, пов'язаного із застосуванням імітаційного моделювання при аналізі логістичних систем. Повна методологія створення концептуальних моделей, орієнтованих на вивчення матеріальних потоків в логістичних мережах, включає в себе принципи побудови наступних часткових моделей:

- моделей структури системи обробки матеріальних потоків;

- моделей асортименту і кількості вантажів в потоках;

- моделей просторової вкладеності вантажів, носіїв вантажу, транспортних засобів і стаціонарних сховищ вантажу;

- тимчасових моделей вхідних потоків системи;

- моделей для визначення тривалості технологічних операцій;

- моделей маршрутизації динамічних об'єктів (транспортних засобів, носіїв вантажу і самих вантажів);

- моделей об'єднання і поділу динамічних об'єктів;

- моделей стратегій обробки черг очікування;

- моделей стратегій управління запасами;

- моделей процесів розподілу ресурсів і диспетчеризації. 
Перша із зазначених часткових моделей є моделлю фізичної (просторової) структури системи. Моделі другого і третього типу служать для відображення структури логістичних об'єктів, що переміщуються і зберігаються в системі. Всі інші моделі складають в сукупності модель процесу, що розвивається в логістичній системі. Переважна більшість імітаційних моделей систем внутрішньої логістики i мереж поставок створюються за допомогою програмних продуктів імітаційного моделювання для процесів з дискретними подіями, таких як Arena, AutoMod, eM-Plant (SIMPLE ++, Plant Simulation), Enterprise Dynamics, Extend, ProModel, QUEST, Simul8 i WITNESS, а також за допомогою універсального імітаційного моделювання AnyLogic. Порівняно нескладні або навчальні моделі створюються також за допомогою мови GPSS, представленого на ринку у формі двох різних продуктів: GPSS World i GPSS / H.

Дискретно-ситуативний підхід. Моделі даного рівня призначені для оцінки ефективності окремих процесів як внутрішньої, так і зовнішньої логістики підприємства. До внутрішньої логістики відноситься переміщення об'єктів всередині всієї території підприємства або в окремих підрозділах. До зовнішньої логістики відноситься перевезення вантажів між різними географічними пунктами із застосуванням засобів транспортування: автомобільного, залізничного, морського і повітряного. Дискретно-ситуативний підхід комплексу моделей можна представити у вигляді трьох типових видів моделей, що охоплюють більшість логістичних процесів внутрішньої і зовнішньої логістики: базова модель (1 продукт - 1 клієнт): мультипродуктова модель (кілька продуктів і клієнтів); багатоланкова (multichain) модель (ланцюжок поставок, багатоклієнтний постачальник - виробник, дилер, оптовий продавець і споживач і т. д.)

Розглянемо мультипродуктову модель, реалізовану в середовищі імітаційного моделювання Arena 13.5. Виробничі потужності випускають три типи продуктів, які поставляються трьох незалежних потоків клієнтів. Вихідний матеріал (сировина) надходить у виробничий процес, а готова продукція зберігається на складі. Замовлення клієнтів надходять в систему, і якщо попит (розмір замовлення) не може бути задоволений поточним запасом готової продукції, то не забезпечена частина замовлення втрачається або затримується. Кожен продукт має власні настроюються параметри попиту і зберігання. Модель складається 3 двох сегментів: управління запасами $\mathrm{i}$ управління попитом. Сегмент управління запасами (рис. 3) моделює виробничі потужності.

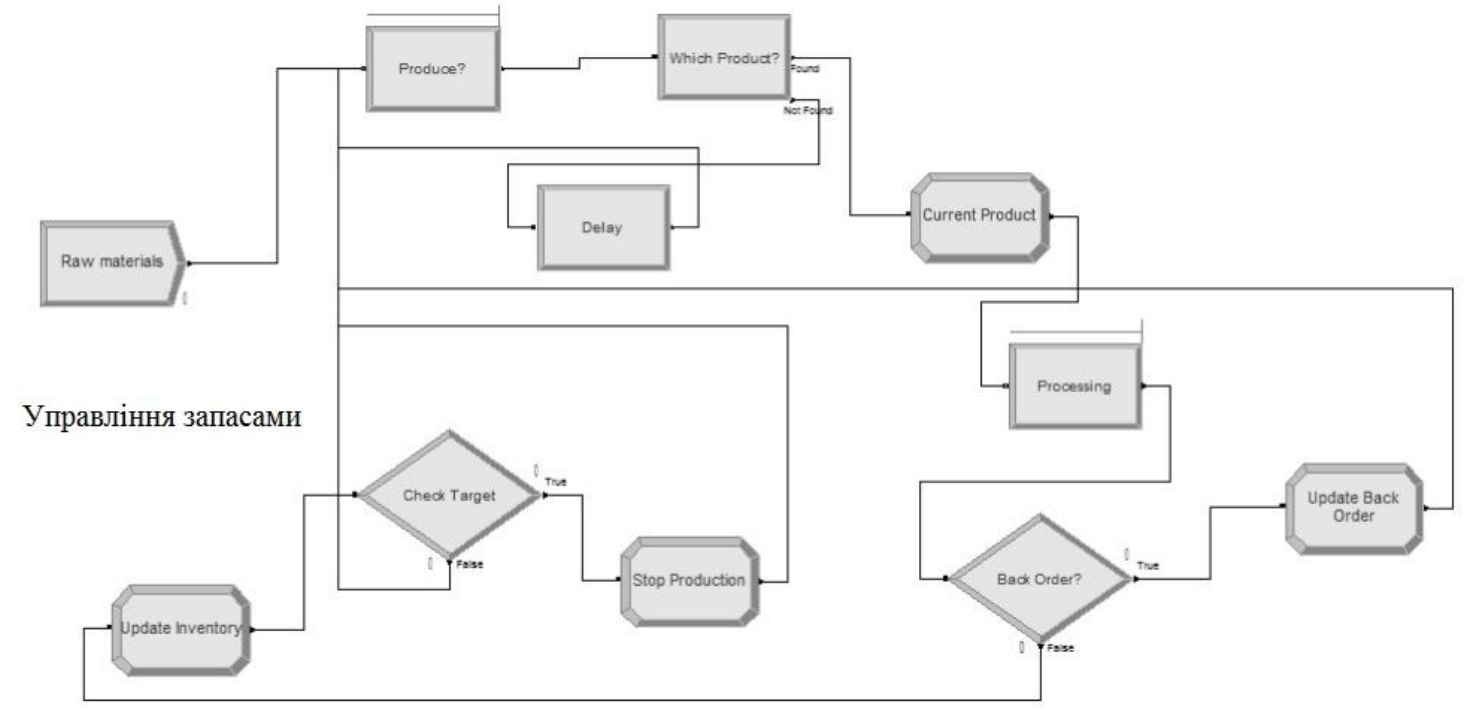

Рисунок 3. Управління запасами

Модуль Create (ім'я Raw Material) генерує одну єдину одиницю, яка управляє процесом виробництва для всіх типів продуктів. Модулі Hold (ім'я Produce?) I Search (ім'я Which Product?) Ініціюють запуск на виробництво одного з типів продуктів, включаючи облік пріоритету продуктів. Модуль Processing імітує виробництво поточного виду продукції. Потім в блоках Decide (iм'я Back Order) i Assign (Update Back order) перевіряється виконання затриманих замовлень, блок Update Inventory оновлює рівень поточних запасів і в завершенні циклу в модулі Decide (iм'я Check Target) перевіряється досягнення цільового рівня запасів. У сегменті управління попитом (рис. 4) моделюється прибуття замовлень на готову продукцію. 


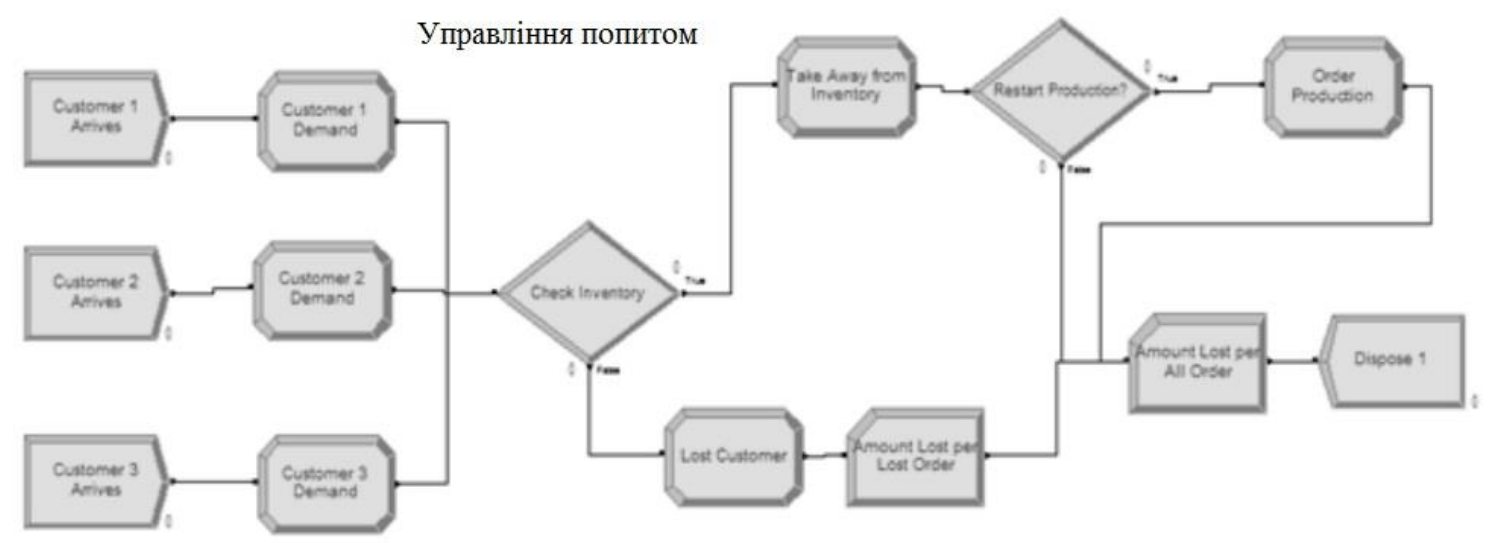

Рисунок 4. Управління попитом

Блоки Create (ім'я Customer 1, 2, 3 Arrives) генерують суті (замовлення клієнтів) на продукти трьох типів, а в модулях Assign (Customer 1, 2, 3 Demand) задаються розміри замовлень, що надійшли. При недостатньому рівні запасів для задоволення поточного замовлення, заявка переходить з виходу модуля Decide (ім'я Check Inventory) в модуль Assign (ім'я Lost Customer), який оновлює статистику по затриманим і невиконаним замовленнях. При наявності достатнього запасу після поновлення поточного рівня запасів в модулі Assign (ім'я Take Away from Inventory) виконується перевірка в модулі Decide (ім'я Restart Production?). Необхідності відновлення запасів для даного типу продуктів, якщо поточний рівень запасів даного типу продукту знизився (менше або дорівнює) до точки замовлення Reorder Level. У моделі можна управляти такими показниками, як початковий рівень запасів на складі, частота надходження замовлень і їх кількість, розмір партії і час виробництва та ін. Тим самим оцінюючи: рівень обслуговування клієнтів (наприклад, частка задоволених вимог замовника, Fill rate). середній рівень запасів (Stock on Hand) i середній рівень затриманих замовлень. швидкість (в одиницю часу) і загальна кількість втрачених або затриманих замовлень (BackOrder i Lost Sales). Таким чином, рівень дискретно-ситуативних моделей використовується для поліпшення параметрів окремих логістичних процесів - процесів фізичного переміщення в часі і просторі матеріальних об'єктів.

Методологія створення дискретно-ситуативних імітаційних моделей, орієнтованих на вивчення матеріальних потоків в логістичних мережах, включає в себе принципи побудови таких окремих моделей:

- моделей структури системи обробки матеріальних потоків;

- моделей асортименту і кількості вантажів в потоках;

- моделей просторової вкладеності вантажів, носіїв вантажу, транспортних засобів і стаціонарних сховищ вантажу;

- тимчасових моделей вхідних потоків системи;

• моделей для визначення тривалості технологічних операцій;

• моделей маршрутизації динамічних об’єктів (транспортних засобів, носіїв вантажу і самих вантажів);

• моделей об'єднання і поділу динамічних об'єктів;

- моделей стратегій управління запасами;

- моделей процесів розподілу ресурсів і диспетчеризації;

Методологія створення дискретно-ситуативних імітаційних моделей може бути розширена 3 урахуванням специфіки об’єкта, що моделюється і досліджуваних логістичних процесах.

Агентні моделі. При наявності великої кількості незалежних клієнтів або територіальнорозподіленого ланцюжка поставок, який характеризується наявністю незалежних учасників, необхідно використовувати агентний підхід. Глобальна поведінка в такій системі виникає, як результат діяльності агентів, кожен з яких слідує своїми власними правилами. Перевагою агентного моделювання є можливість оцінки ефективності взаємодії агентів один $з$ одним, а саме: агенти обмінюються необхідною інформацією (кількість замовлень, розподіл попиту і т.п.) і приймають рішення на підставі отриманих даних, що знижує ризик появи ефекту «хлиста». Моделювання спілкування агентів допомагає виявляти позитивний або негативний ефект від дій одного агента на іншого. Наприклад, експерименти 3 агентною моделлю ланцюга поставок допоможуть менеджеру 
проаналізувати вплив обміну інформацією партнерів на рівень запасів і вибрати оптимальну стратегію для мінімізації витрат на їх зберігання.

\section{ОБГОВОРЕННЯ РЗУЛЬТАТІВ ДОСЛІДЖЕНЬ}

Імітаційне моделювання логістичних систем різного призначення $\epsilon$ в індустріально розвинених країнах цілком звичайною складовою частиною проектів, спрямованих на створення нових або реконструкцію існуючих логістичних систем. У Західній Європі та США є досить багато фірм, які пропонують таке моделювання як основний або додатковий вид послуг, які виконуються в рамках консалтингових або проектних робіт. При цьому у замовників давно склалася думка, що розробку складних (i, отже, дорогих) моделей можна доручати тільки фахівцям, що мають статус експертів в області імітаційного моделювання логістичних систем, які:

- володіють базовими інженерними та економічними знаннями, необхідними для розуміння принципів функціонування певних класів логістичних систем;

- володіють методами системного аналізу та управління проектами, необхідними для коректної постановки задачі моделювання та організації всіх етапів робіт по реалізації та використання моделей;

- володіють незалежними від конкретних моделей загальними методами імітаційного моделювання, особливо, математичними методами;

- володіють методами роботи з одним або декількома підходами імітаційного моделювання і вміють створювати власні комп'ютерні програми;

- знайомі з сучасними інформаційними технологіями, що забезпечують інтеграцію моделей в системах проектування, планування та управління.

\section{ВИСНОВКИ}

У статті розглядається застосування різних підходів імітаційного моделювання для оцінки ефективності логістичних процесів. Представлена узагальнена структура імітаційної моделі функціонування логістичної системи. Для іiі реалізації запропоновано використання трирівневого комплексу моделей, що використовують різні парадигми імітаційного моделювання (системна динаміка, дискретно-ситуативний підхід, агентний підхід). Визначено призначення моделей кожного рівня: системна динаміка - для проектування загальної структури логістичної системи; дискретноситуативний підхід - для поліпшення параметрів окремих логістичних процесів; агентний підхід для незалежного територіально-розподіленого ланцюжка поставок. Запропоновано приклад реалізації рівня дискретно-ситуативних моделей у вигляді трьох типових видів моделей. У середовищі імітаційного моделювання Arena розроблена мультипродуктова модель для оцінки базових показників ефективності логістичної системи: рівень обслуговування (Fill rate), середній рівень запасів (Stock on Hand), середній рівень затриманих замовлень, загальна кількість втрачених або затриманих замовлень (BackOrder i Lost Sales). В ході подальшої роботи планується наповнення запропонованого комплексу моделей з використанням всіх трьох підходів імітаційного моделювання. В цілому можна зробити висновок, що застосування переваг кожного із підходів імітаційного моделювання $є$ перспективним і може бути використаний для широкого кола підприємств різних галузей діяльності.

\section{ПЕРЕЛІК ДЖЕРЕЛ ПОСИЛАННЯ}

1. Гаджинский А.М. Логистика: Учебник для вузов. - 20-е изд., перераб. и доп. // М.: Дашков и К, 2012. $-484 \mathrm{c}$.

2. Рожков М.И. Имитационное моделирование логистических сетей поставщиков в автомобильной промышленности // Логистика и управление цепями поставок. - 2012. - № 2. - С . 40 49.

3. Толуев Ю.И. Методология создания моделей логистических сетей на базе стандартных средств имитационного моделирования // Logistics, Supply Chain Management and Information Technologies: Proceedings of the German-Russian Logistics Workshop. Ivanov D., Kuhn A., Lukinsky V. (eds.), St. Petersburg, Publishing House of the State Polytechnic University, 2006. - P. 133-142.

4. Cachon G., Terwiesch C. «Matching Supply With Demand: An Introduction To Operations Management» // 2008, McGraw-Hill Higher Education s. 486.

5. Terzi S., Cavalieri S. «Simulation in the supply chain context: a survey», // Computers in Industry. 2004.Vol. 53. P. 3 - 16. 


\section{REFERENCES}

1. Gadginckii A. M. Logistika: Ychebnik dlia vyzov. - 20-e izd., pererab. i dop. // M.: Dashkov i K, 2012. $-484 \mathrm{c}$.

2. Rogkov M. I. Imitatsionoe modelirovanie logisticheskih setey postavchikov $\mathrm{v}$ avtomobilnoj promushlenosty // Logistika I ypravlenie tsepiami postavok. - 2012. - № 2. - C . 40 - 49 .

3. Tolyev Yu.I. Metodologyia sozdania modeley logisticheskih setey na baze standartnuh sredstv imitatsionnogo modelirovania // Logistics, Supply Chain Management and Information Technologies: Proceedings of the German-Russian Logistics Workshop. Ivanov D., Kuhn A., Lukinsky V. (eds.), St. Petersburg, Publishing House of the State Polytechnic University, 2006. - P. 133-142.

4. Cachon G., Terwiesch C. «Matching Supply With Demand: An Introduction To Operations Management»// 2008, McGraw-Hill Higher Education s. 486.

5. Terzi S., Cavalieri S. «Simulation in the supply chain context: a survey», // Computers in Industry. 2004.Vol. 53. P. 3 - 16.

\section{Samostian. Efficient use of approaches for simulation modeling of logistics processes}

In industrialized countries, simulation of logistics chains is widely used and is considered a common part of projects to create new or renovate existing logistics chains. In this article, three approaches to simulation modeling of logistics systems were considered. The application of different approaches of simulation modeling to evaluate the efficiency of logistics processes was considered. The generalized structure of the simulation model of the logistics system functioning is presented. To implement it, the use of a three-level set of models using different paradigms of simulation modeling is proposed. The advantages of each of the approaches of simulation modeling of logistics processes were considered and outlined, in particular: system dynamics, discrete-situational approach, agent approach. The purpose of the models of each approach is determined: system dynamics - for designing the general structure of the logistics system; discrete-situational approach - to improve the parameters of individual logistics processes; agent approach for an independent territorially distributed supply chain. For example, a generalized simulation model of the logistics system in the form of a "black box" was taken. An example of realization of the level of discretesituational models in the form of three typical types of models is offered. In the simulation environment Arena developed a multi-product model to assess the basic performance of the logistics system: the level of service, the average level of stocks, the average level of delayed orders, the total number of lost or delayed orders.

In the course of further work it is planned to fill the proposed set of models using all three approaches of simulation. In general, we can conclude that the application of the advantages of each of the approaches to simulation is promising and can be used for a wide range of enterprises in different industries.

Keywords: simulation modeling, logistics system, discrete-situational approach, agent approach, supply chains, supplier.

САМОСТЯН Віктор Русланович, кандидат технічних наук, доцент кафедри інженерної та комп'ютерної графіки, Луцький національний технічний університет e-mail: cvmbf@ukr.net. http://orcid.org/0000-0001-6823-8558

Viktor SAMOSTIAN, $\mathrm{PhD}$ in Engeneering, associate professor of engineering and computer graphics department, Lutsk National Technical University e-mail: cvmbf@ukr.net. http://orcid.org/0000-0001-6823$\underline{8558}$

DOI 10.36910/automash.v2i15.400 